\title{
Nature relatedness of pre-service teachers
}

\author{
Ferhat Karakaya \\ Kahramanmaraş Sütçüimam University, Faculty of Education, Kahramanmaraş, Turkey, ferhatk26@gmail.com \\ Sakine Serap Avgın \\ Kahramanmaraş Sütçüimam University, Faculty of Education, Kahramanmaraș, Turkey, serapavgin@hotmail.com \\ Elif Gömlek \\ Kahramanmaraş Sütçüimam University, Faculty of Education, Kahramanmaraş, Turkey, elif.gomlek.80@gmail.com \\ Merve Balik \\ Kahramanmaraş Sütçüimam University, Faculty of Education, Kahramanmaraş, Turkey, evrem466@gmail.com
}

\begin{abstract}
In this research, it was aimed to determine the nature relatedness of pre-service primary school and science teachers regarding various variables. "Nature Relatedness Scale (NRS)", developed by Nisbet, Zelenski and Murphy (2009) and adapted to Turkish and analyzed, terms of validity by Çakır, Kararslan , Şahin and Ertenpınar (2015), was used as data collection instrument. The research was carried out with 363 pre-service teachers in Kahramanmaraş Sütçü İmam University in the academic year of 2015-2016. The relational screening model was used in the research, in which and, statistical significance of the obtained data was determined through independent $t$ test, one-way variance analysis Kruskal-Wallis analysis and Tukey meaningfulness tests. Research findings have indicated a; difference among the participants' nature relatedness in relation to gender, education, and grade level. However, no significant was difference found between having taken the environment lesson, membership to natural organizations, participation in natural activities nature relatedness of pre-service teachers.
\end{abstract}

Keywords Nature relatedness, nature education, environmental education, prospective teacher

\section{Öğretmen adaylarının doğa ile ilişkileri}

ÖZ Bu araştırmada, fen bilgisi ve sınıf öğretmenliği programlarında okuyan öğretmen adaylarının doğa ile ilişkilerinin çeşitli değişsenlere göre belirlenmesi amaçlanmıştır. Araştırmada, Nisbet, Zelenski ve Murphy (2009) tarafından geliştirilen Çakır, Karaarslan, Şahin ve Ertepınar (2015) tarafından Türkçeye uyarlanarak geçerlik ve güvenirlik analizleri yapılan "Doğayla İlişki Ölçeği (DİÖ)"' kullanılmıştır. Çalışma 2015-2016 eğitim öğretim yllında Kahramanmaraş Sütçü İmam Üniversitesinde öğrenim gören 363 öğretmen adayı ile yürütülmüştür. İlişkisel tarama modelinin kullanıldığ belirlenmesi bağımsız t testi, tek yönlü varyans analizi Kruskal-Wallis analizi ve Tukey anlamlılık testleriyle yapılmıştır. Araştırma bulgularına göre; cinsiyet, öğrenim görülen bölüm ve sınıf düzeyi öğretmen adaylarının doğayla ilişkilerinde anlamlı farklılık $(p<.05)$ oluşturmuş̧ur. Ancak öğretmen adaylarının doğayla ilişkilerinde çevre dersi alma durumu, doğa kuruluşuna üye olma durumu ve doğa etkinliğine katılma durumu değişkenlerine göre anlamlı farklılık olmadığı tespit edilmiştir.

Anahtar

Doğa ilişkisi, doğa eğitimi, çevre ĕgitimi, öğretmen adayı 


\section{INTRODUCTION}

Nature is a system, which is created without human effect, which has its own mechanisms with no boundaries without showing variability in terms of living and nonliving elements; and which has the characteristics of being effective and effected, changing and able to change, and being renewable (Atasoy, 2006). The fact that the human influences are not felt, or the idea that environment cannot be changed to a great extent comes into human mind when natural environment, natural activities and forces are concerned. In order for human beings to continue their life, they create the artificial environment, which is different from natural one, by using the resources in natural environment, improving technology and realising financial activities. While trying to improve the living conditions of artificial environment, they are always in communication with the nature (Ertan, 1991). Human being is an entity that directs his life through the effects of conditions within nature and can exist necessarily in relation to nature. Human is a living species that has to live in relation to nature. This forced relationship is shaped around human being's own needs and foresights, and s/he chooses the way to centralize his own position from a unilateral attitude to the effect of nature (Gül, 2013). Ever since human beings began to live on earth, they have tried to create an artificial environment of their own, which has caused the relationship between human beings and nature to constantly evolve against nature. There is a constant battle between the natural environment and the artificial environment. While the natural environment is degraded by human, the artificial environment is expanding. (Ertan, 1991). It is necessary to organize education about the subject from the early ages in order to be aware of the growth that occurs in the artificial environment and to develop environmentally sensitive behaviors (Çabuk, 2001).

The majority of human identity occur in the early years of childhood (0-12 years), according to developmental psychology surveys. Stage theorists studied human development in terms of different stages and consequently concluded that childhood characteristics of human development are largely influencing other periods (Onur, 1995). This result in the field of developmental psychology also supports the results of studies in medicine (Çukur \& Özgüner, 2008). For example, according to the children meat is sold in the butcher shop, a food from the egg grocery store and Milk, bottles, or carton boxes. Today's people, starting from childhood, are watching dreams that are produced in a way disconnected from the realities of nature, listening to the stories and reading them (Ökten, 1985).

When the literature is analyzed, it is seen that the attitudes of the individuals in different groups towards environment and nature and their relations have been/ were investigated in various forms. Aksoy and Karatekin (2011) examined the affective tendencies of undergraduate students studying in different programs in terms of different variables and revealed. It was determined that the female prospective teacher were higher in this study than the male prospective teacher. Altınöz (2010) conducted a study to reveal the environmental literacy levels of science teacher candidates. As a result of the research, it has been determined that environmental literacy levels of science teacher candidates are moderate. Aydin (2010) conducted a survey to determine geographical teacher candidates' views on environmental issues and education. As a result of the research it is understood that geography teacher candidates' social and academic sensitivity about environment problems and environment education is extremely high. Çabuk and Karacaoğlu (2003) conducted a study on examining the environmental sensitivities of university students. According to the opinions of the students, it has been reached that there is not enough education about air, water and soil pollution in organized education institutions and environmental sensitivities of students according to some personal characteristics. Ek, Kılıç, Öğdüm, Düzgün and Şeker (2009) conducted a study to determine the attitudes and sensitivities of first and last year students in different departments of the university to environmental problems. It has been determined that various variables affect the attitudes and behaviors of university students in preventing environmental problems in the study. Kahyaoğlu, Daban and Yang (2008) investigated the attitudes of the elementary school teachers to the environment and as a result they found that the program they were in possessed different perspectives for the neighborhood in terms of class level. Kayalı (2010) investigated the attitudes of students of social studies, Turkish and classroom teaching to environmental problems. As a result of the research, it was determined that the teacher candidates generally have a positive attitude towards environmental problems. Sam, Gürsakal and Sam (2010) conducted a study to determine the environmental risk perceptions and environmental attitudes of university students. In the study, it was found that the sensitivity of female students to environment was higher than that of male students, the sensitivity increased as the level of the students were higher, have affected the environmental sensitivity 
significantly. Sam, Öngen and Sam (2010) investigated whether university students' environmental attitudes are related to their self-esteem. As a result of the study, it was revealed that the average of the environment-centered approach of the female students was higher than the male students, and that there was a positive and meaningful relationship between the students' environmentalist approaches and their self-esteem. Aksu (2009) as a result of the research on science and technology and classroom teachers stated that, most of the teachers think that the sensitivity of the society to the environment is inadequate, the sensitivity of the students is moderate, and their sensitivity is good. Meydan and Doğu (2008) evaluated the opinions of primary school second graders about environmental problems according to some variables. As a result of the study, the students' opinions on environmental problems were changed according to the classes and ages of education and there was no difference according to gender. Nature Relation Scale which is used in this study and developed by Nisbet et al. (2009), is different from other scales developed in the subject, including the physical relationship established with nature such as dealing with the land, being in natural areas and preferring these areas as a holiday place. This scale provides the researcher with the opportunity to evaluate the nature, emotional, cognitive and physical relationships of the individuals together at the same time.

Teachers constitute the core of this education along with the families. The basis of this education is the teachers together with the families. As in every stage of education, it is aimed to educate individuals to be sensitive to the environment and to have a positive environmental attitude from the primary education onwards . In order to provide nature education in an effective and qualified manner in the first stage of primary education, teachers are expected to be well trained in nature education. That is, it is considered beneficial to determine the nature relatedness of pre-service teachers. This aim could only be achieved with qualified teachers who attach sufficient importance to nature education. Accordingly, the aim of the research is outlined in the following subsection.

\section{Aim of the research}

In this research, it was aimed to determine the nature relatedness of pre-service primary school and science teachers regarding various variables. Within the scope of this aim, the following research questions were addressed:

Is there a difference in nature relatedness of pre-service teachers in terms of gender?

Is there a difference in nature relatedness of pre-service teachers in terms of having an environment lesson?

Is there a difference in nature relatedness of pre-service teachers in terms of the education department? Is there a difference in nature relatedness of pre-service teachers in terms of participation in a nature activity?

Is there a difference in nature relatedness of pre-service teachers in terms of being a member of a nature organization?

Is there a difference in nature relatedness of pre-service teachers in terms of grade level?

The following section outlines research design of the study providing information about study group of research, data collection instrument, and data analysis.

\section{METHODOLOGY}

\section{Research model}

In this research, relational screening model was used to investigate nature relatedness of the pre-service teachers regarding various variables. The screening model is a method that aims to achieve generalized beliefs on a sample selected from the universe or universe consisting of many elements (Karasar, 2006). The relational screening model, on the other hand, is a scanning model that consists of two or more variables and that examines the relationship between variables (Karasar, 2006).

\section{Data collection instrument}

As a data collection tool; Nature Relatedness Scale (NRS) developed by Nisbet, Zelenski and Murphy (2009) and adapted to Turkish and analyzed, terms of validity by Çakır, Kararslan, Şahin and Ertenpınar (2015), was used as data collection instrument. The relationship with nature scale consists of three subdimensions as "Self-confidence", "Perspective" and "Experience" and a total of 21 questions. Questions on the scale are evaluated by numbering 1 = absolutely disagree, 2 = disagree, 3 = unstable, $4=$ agree, $5=$ strongly agree. The reliability of this research scale was found to be cronbach alpha number of 0.74 . 


\section{Data analysis}

IBM SPSS 21 Statistics program was used for analyzing the obtained data. In assessment of the items 5-Likert type scoring from "(1) not very important” to "(5) very important” was used. The data were analysed through the Independent Sample t-test, and One-way ANOVA.

\section{Study group of research}

The research was carried out with participation of 363 pre-service teachers in Kahramanmaraş Sütçü İmam University in the academic year of 2015-2016. Demographics of the pre-service teachers are presented in Table 1.

Table 1

The demographic information of the pre-service teachers

\begin{tabular}{llll}
\hline \multicolumn{2}{c}{ Demographical Information } & f & $\%$ \\
\hline \multirow{2}{*}{ Gender } & Female & 279 & 76.9 \\
& Male & 84 & 23.1 \\
Department & Science education & 177 & 48.8 \\
& Primary school education & 186 & 51.2 \\
& $1^{\text {st }}$ Grade & 137 & 37.7 \\
Grade Level & $2^{\text {nd }}$ Grade & 53 & 14.6 \\
& $3^{\text {rd }}$ Grade & 53 & 14.6 \\
Having a class about nature & $4^{\text {th }}$ Grade & 120 & 33.1 \\
& Yes & 205 & 56.5 \\
Attending to a nature activity & No & 158 & 43.5 \\
& Yes & 172 & 47.4 \\
Membership to nature organization & No & 191 & 52.6 \\
& Yes & 54 & 14.9 \\
& No & 309 & 85.1 \\
\hline
\end{tabular}

When data on Table 1 is analyzed, $76.9 \%(n=279)$ of pre-service teachers are females and $23.1 \%(n=84)$ of these teachers are males. The finding of the research is described in the following section.

\section{FINDINGS}

Within the scope of the aim of research, findings of research questions are presented below. Firstly, in the research, question of "Is there a difference in nature relatedness of pre-service teachers in terms of gender" was investigated. The independent t-test results are given in Table 2.

Table 2

The results of t-test for gender variable

\begin{tabular}{|c|c|c|c|c|c|c|}
\hline Department & Gender & $\mathrm{N}$ & $\overline{\bar{Z}}$ & sd & $t$ & $p$ \\
\hline Science education & $\begin{array}{l}\text { Female } \\
\text { Male }\end{array}$ & $\begin{array}{l}147 \\
30\end{array}$ & $\begin{array}{l}3.20 \\
3.43\end{array}$ & 175 & -2.607 & $.010^{*}$ \\
\hline Primary school education & $\begin{array}{l}\text { Female } \\
\text { Male }\end{array}$ & $\begin{array}{l}132 \\
54\end{array}$ & $\begin{array}{l}3.18 \\
2.98\end{array}$ & 184 & 3.131 & $.002 *$ \\
\hline
\end{tabular}

${ }^{*} p<.05$

When the the results in Table 2 were examined, there was significant difference nature relatedness of in terms of gender. It could be claimed that gender is an effective factor for nature relatedness of preservice science teachers $(t(175)=-2.607 ; p<.05)$ and pre-service primary school teachers $(t(184)=$ $3.131 ; p<.05)$. Additionally, while female pre-service science teachers mean score of nature relatedness is $(x=3.20)$, mean score of male pre-service science teachers is $(x=3.43)$. When female and male preservice science teachers mean scores were compared, it can be said that nature relatedness of male preservice science teachers is less than nature relatedness of female pre-service science teachers. While female pre-service primary school teachers mean score of nature relatedness is $(x=3.18)$, mean score of male lecturers is $(\mathrm{x}=2.98)$. When female and male pre-service primary school teachers mean scores were compared, it can be said that nature relatedness of male pre-service primary school teachers is less than nature relatedness of female pre-service primary school teachers. 
In the research, question of "Is there a difference in nature relatedness of pre-service teachers in terms of having an evironment lesson?' ' was investigated. The independent t-test results were given in Table 3.

Table 3

The results of t-test for having an environment lesson variable

\begin{tabular}{lclllll}
\hline Department & Having an environment lesson & $\mathrm{N}$ & $\overline{\mathcal{X}}$ & $\mathrm{sd}$ & $t$ & $p$ \\
\hline \multirow{2}{*}{ Science education } & Yes & 107 & 3.28 & \multirow{2}{*}{175} & 1.596 & .112 \\
& No & 70 & 3.17 & & & \\
\multirow{2}{*}{ Primary school education } & Yes & 98 & 3.08 & 184 & -1.568 & .119 \\
\hline
\end{tabular}

${ }^{*} p<.05$

When the the results in Table 3 were examined, there was no significant difference nature relatedness of in terms of having an environment lesson. It could be claimed that having an environment lesson is not an effective factor for nature relatedness of pre-service science teachers $(t(175)=1.596 ; p>.05)$ and pre-service primary school teachers $(t(184)=-1.568 ; p>.05)$.

In the research, question of "Is there a difference in nature relatedness of pre-service teachers in terms of education department?' ' was investigated. The independent t-test results were given in Table 4.

Table 4

The results of t-test for education department variable

\begin{tabular}{lllllll}
\hline Scale & Department & $\mathrm{N}$ & $\overline{\mathbb{X}}$ & sd & $t$ & $p$ \\
\multirow{2}{*}{ NRS } & Science education & 177 & 3.24 & \multirow{2}{*}{361} & \multirow{2}{*}{2.579} & \multirow{2}{*}{$.01^{*}$} \\
& Primary school education & 186 & 3.12 & & & \\
\hline
\end{tabular}

${ }^{*} p<.05$

When the the results in Table 4 were examined, there was a significant difference nature relatedness of in terms of education department $(t(361)=2.579, p<.05)$. It could be claimed that education department is an effective factor for nature relatedness of pre-service science teachers and pre-service primary school teachers. Additionally, while pre-service science teachers mean score of nature relatedness is ( $\overline{\mathbb{B}}=3.24)$, mean score of pre-service primary school teachers is $(\overline{\mathbb{B}}=3.12)$. When pre-service science teachers and pre-service primary school teachers mean scores were compared, it can be said that nature relatedness of pre-service primary school teachers is less than nature relatedness of pre-service science teachers.

In the research, question of "Is there a difference in nature relatedness of pre-service teachers in terms of participation in a nature activity?" was investigated. The independent t-test results were given in Table 5.

Table 5

The results of t-test for participation in a nature activity variable

\begin{tabular}{lclllll}
\hline Department & Attendance to an Act. & $\mathrm{N}$ & $\overline{\mathbb{X}}$ & sd & $t$ & $p$ \\
\hline \multirow{2}{*}{ Science education } & Yes & 96 & 3.24 & \multirow{2}{*}{175} & \multirow{2}{*}{.143} & \multirow{2}{*}{.887} \\
\multirow{2}{*}{ Primary school education } & No & 81 & 3.23 & & & \\
& Yes & 76 & 3.06 & & & \\
& No & 110 & 3.17 & & -1.345 & .180 \\
\hline
\end{tabular}

${ }^{*} p<.05$

When the the results in Table 5 were examined, there was not significant difference nature relatedness of in terms of participation in a nature activity. It could be claimed that participation in a nature activity is not an effective factor for nature relatedness of pre-service science teachers $(t(175)=.143 ; p>.05)$ and pre-service primary school teachers $(t(184)=-1.345 ; p>.05)$.

In the research, question of "Is there a difference in nature relatedness of pre-service teachers in terms of being a member of a nature organization?" ' was investigated. The independent t-test results were given in Table 6. 
Table 6

The results of t-test for being a member of a nature organization variable

\begin{tabular}{lclllll}
\hline Department & Membership & $\mathrm{N}$ & $\overline{\mathbb{Z}}$ & $\mathrm{sd}$ & $t$ & $p$ \\
\cline { 2 - 7 } Science education & Yes & 25 & 3.36 & \multirow{2}{*}{175} & \multirow{2}{*}{1.495} & \multirow{2}{*}{.137} \\
& No & 152 & 3.22 & & & \\
\multirow{2}{*}{ Primary school education } & Yes & 29 & 3.06 & 184 & -.924 & .357 \\
& No & 157 & 3.13 & & \\
\end{tabular}

$* p<.05$

When the the results in Table 6 were examined, there was not significant difference nature relatedness of in terms of participation in a nature activity. It could be claimed that being a member of a nature organization is not an effective factor for nature relatedness of pre-service science teachers $(t(175)=$ $1.495 ; p>.05)$ and pre-service primary school teachers $(t(184)=-.924 ; p>.05)$.

In the research, question of "Is there a difference in nature relatedness of pre-service teachers in terms of grade level?" ' was investigated. The obtained one-way analysis of variance (anova) results were given in Table 7 and Kruskal-Wallis results were provided on Table 8.

Table 7

The results of one-way ANOVA test for grade level variable

\begin{tabular}{|c|c|c|c|c|c|c|c|c|c|c|}
\hline & Grade & $\mathrm{f}$ & $\overline{\mathcal{Z}}$ & Squares Sum & sd & $\begin{array}{l}\text { Squares } \\
\text { Average }\end{array}$ & $F$ & $p$ & Tukey & \\
\hline \multirow{4}{*}{$\begin{array}{l}\text { Primary school } \\
\text { education }\end{array}$} & $1^{\text {st }}$ & 90 & 3.21 & $\begin{array}{l}\text { Between } \\
\text { Groups }\end{array}$ & 1.473 & 3 & .491 & \multirow{4}{*}{2.937} & \multirow{4}{*}{$.035^{*}$} & \multirow{4}{*}{$1>2$} \\
\hline & $2^{\text {nd }}$ & 26 & 2.99 & In Groups & 30.428 & 182 & \multirow{3}{*}{.167} & & & \\
\hline & $3^{\text {rd }}$ & 32 & 3.06 & All & 31.901 & 185 & & & & \\
\hline & $4^{\text {th }}$ & 38 & 3.05 & & & & & & & \\
\hline
\end{tabular}

When the the results in Table 7 were examined, there was significant difference nature relatedness of in terms of grade level. It can be said that grade level is an effective factor for nature relatedness of preservice primary school teachers' $[F(3,182)=2.937 ; p<.05]$. Additionally, while $1^{\text {st }}$ grade pre-service primary school teachers mean score of nature relatedness is ( $\overline{\mathbb{Q}}=3.21)$, mean score of $2^{\text {nd }}$ grade pre-service primary school teachers' is ( $\overline{\mathbb{B}}=2.99)$. When $1^{\text {st }}$ and $2^{\text {nd }}$ pre-service primary school teachers' mean scores were compared, it can be said that nature relatedness of $2^{\text {nd }}$ pre-service primary school teachers'is less than nature relatedness of $1^{\text {st }}$ pre-service primary school teachers.

Table 8

The results of kruskal- wallis variance analysis test for grade level variable

\begin{tabular}{|c|c|c|c|c|c|c|c|}
\hline & Grade & $\mathrm{N}$ & $\overline{\bar{Z}}$ & Sira Ort. & $\mathrm{Sd}$ & $\mathrm{X}^{2}$ & $p$ \\
\hline \multirow{4}{*}{ Science education } & $1^{\text {st }}$ & 47 & 3.13 & 80.21 & \multirow{4}{*}{2} & \multirow{4}{*}{2.942} & \multirow{4}{*}{.401} \\
\hline & $2^{\text {nd }}$ & 27 & 3.26 & 98.13 & & & \\
\hline & $3^{\mathrm{rd}}$ & 21 & 3.17 & 82.95 & & & \\
\hline & $4^{\text {th }}$ & 82 & 3.31 & 9258 & & & \\
\hline All & & 177 & 3.24 & & & & \\
\hline
\end{tabular}

${ }^{*} p<.05$

When the the results in Table 8 were examined, there was not significant difference nature relatedness of in terms of grade level. It could be claimed that grade level is not an effective factor for nature relatedness of pre-service science teachers $\left(X^{2}=14,375 ; p>.05\right)$.

\section{DISCUSSION and CONCLUSION}

In this research, it was aimed to determine the nature relatedness of pre-service primary school and science teachers regarding various variables.

There was statistically significant difference nature relatedness of pre-service science teachers and primary school teachers in terms of gender. That is, gender is an effective factor on nature relatedness 
of pre-service science teachers and pre-service primary school teachers. When female and male preservice primary school teachers mean scores were compared (Table 2), it can be said that nature relatedness of male pre-service primary school teachers is less than nature relatedness of female preservice primary school teachers. Similar to this finding, Kahyaoğlu, Daban ve Yangın (2008) found that an environmental attitudes of male pre-service primary school teachers is less than female pre-service science teachers. Meydan and Doğu (2008), Ek and others (2009), Erol and Gezer (2006) found that attitudes towards environmental problems are higher for women. These results support the findings of this research. On the contrary, this research was found that male pre-service science teachers have more nature relatedness of levels compared to female pre-service science teachers. This is an interesting result.

There was no statistically significant difference in nature relatedness of pre-service science teachers' and pre-service primary school teachers in terms of having an environment lesson. That is, having an environment lesson is not an effective factor on nature relatedness of pre-service science teachers and pre-service primary school teachers. However, it is interesting that environment lesson effect positive on nature relatedness of pre-service science teachers. On the contrary, it found that environment lesson effect negative on nature relatedness of pre-service primary school teachers. Similar to this finding, Aksoy and Karatekin (2011) found that the environmental education courses that prospective teachers had taken in the university did not have a positive effect on their environmental perception tendencies. Erol and Gezer (2006), Kahyaoğlu and et al. (2008) found that there was no significant difference in the affective tendencies of students who took environmental education courses. On the contray these results, Kayalı (2010), Altınöz (2010), Sam, Gürsakal and Sam (2010) found that the attitudes of pre-service teachers who had environment lessons before towards the environment are higher than pre-service teachers who did not see the environment lessons.

There was a statistically significant difference nature relatedness of prospective science teachers and primary school teachers in terms of education department. That is, education department is an effective factor on nature relatedness of pre-service teachers. Similar to this finding, Aksoy and Karatekin (2011) determined that the nature relatedness of pre-service primary school teachers and social studies teachers is less than nature relatedness of pre-service science teachers. Çabuk and Karacaoğlu (2003), Aksu (2009), Kahyaoğlu and et al. (2008) found that education department is an effective factor on environmental attitudes, environmental sensitivities of pre-service teachers. These results support the findings of this research.

There was no statistically significant difference nature relatedness of pre-service science teachers and pre-service primary school teachers in terms of participation in a nature activity. That is, participation in a nature activity is not an effective factor on nature relatedness of pre-service science teachers and pre-service primary school teachers. However it was found that participation in a nature activity affect negatively the nature relatedness of pre-service primary school teachers.

There was no statistically significant difference nature relatedness of pre-service science teachers and pre-service primary school teachers in terms of being a member of a nature organization. That is, being a member of a nature organization is not an effective factor for nature relatedness of pre-service science teachers and pre-service primary school teachers. However it was found that being a member of a nature organization effect negatively the nature relatedness of pre-service primary school teachers.

There was statistically significant difference in nature relatedness of pre-service primary school teachers in terms of grade level. When $1^{\text {st }}$ grade and $2^{\text {nd }}$ pre-service primary school teachers mean scores were compared (Table 7), it can be said that nature relatedness of $2^{\text {nd }}$ pre-service primary school teachers is less than nature relatedness of $1^{\text {st }}$ pre-service primary school teachers. That is, grade level is an effective factor on nature relatedness of pre-service primary school teachers. Similar to this finding, Ek et al. (2009) found that the average of senior students was higher by examining the relationship between environmental attitudes and grade levels of students who were studying at university. These result support the findings of this research. However, there was no statistically significant difference nature relatedness of pre-service science teachers in terms of grade level. Aydın (2010) and Sam and Öngen (2010) found that the grade level is not effective on environmental attitudes in their studies.

This research has determined the nature relatedness of pre-service teachers by different variables. It showed that nature relatedness of pre-service teachers were not at an adequate level. It were found that studies and activities were needed to increase the nature relatedness of pre-service teachers. Further, it was considered that nature relatedness of pre-service teachers should be examined according to 
independent variables. Because teachers have great responsibilities not only in education but also in different discipline (social, moral, environmental, etc). Teachers are engaged in the training of environmentally sensitive individuals and societies. Therefore, nature relatedness of pre-service teachers should be strongly.

Acknowledge: Some findings of this research was presented as an oral paper at the 3rd National Environmental Congress 24- 28 Eylül 2016, Marmaris, Turkey.

\section{REFERENCES}

Aksoy, B., \& Karatekin, K. (2011). Farklı programlardaki lisans öğrencilerinin çevreye yönelik duyuşsal eğilimleri. Türkiye Sosyal Araştırmalar Dergisi, 15(3), 23-36.

Aksu, Y. (2009). Fen ve Teknoloji ile sinıf ögretmenlerinin çevre sorunlarına yönelik tutumlarının belirlenmesi (Burdur İli Örneği). Süleyman Demirel Üniversitesi, Yayımlanmamış yüksek lisans tezi, , Isparta.

Altınöz, N. (2010). Fen Bilgisi öğretmen adaylarının çevre okuryazarlık düzeyleri. Sakarya Üniversitesi, Yayımlanmamış Yüksek Lisans Tezi, Sakarya.

Atasoy, E. (2006). Çevre İçin Eğitim: Çocuk-Doğa Etkileşimi. Ezgi Kitabevi.

Aydın, F. (2010). Coğrafya öğretmen adaylarının çevre sorunları ve çevre eğitimi hakkındaki görüşleri (Gazi Üniversitesi Örneği). International Online Journal of Educational Sciences, 2(3), 818-839.

Çabuk, B. (2001). Okul öncesi dönem çocuklarının çevre ile ilgili farkındalık düzeyleri. Ankara Üniversitesi, Yayınlanmamış Yüksek Lisans Tezi, Ankara.

Çabuk, B., \& Karacaoğlu, C. (2003). Üniversite öğrencilerinin çevre duyarlılıklarının incelenmesi. Ankara Üniversitesi Eğitim Bilimleri Fakültesi Dergisi, 36(1-2), 189-198.

Çakır, B., Karaarslan, G., Şahin, E., \& Ertepınar, H. (2015). Adaptation of nature relatedness scale to Turkish. Elementary Education Online, 14(4), 1370-1383.

Çukur, D., \& Özgüner, H. (2008). Kentsel alanda çocuklara doğa bilinci kazandırmada oyun mekanı tasarımının rolü. Süleyman Demirel Üniversitesi Orman Fakültesi Dergisi, (2), 177-187.

Ek, N., H., Kılıç, N., Öğdüm, P., Düzgün, G. ve Şeker, S. (2009). Adnan Menderes Üniversitesinin farklı akademik alanlarında öğrenim gören ilk ve son sınıf öğrencilerinin çevre sorunlarına yönelik tutumları ve duyarlılıkları. Kastamonu Ĕ̈itim Dergisi, 17(1), 125-136.

Erol, H. G. \& Gezer, K. (2006). Prospective of elementary school teachers' attitudes toward environment and environmental problems, International Journal of Environmental and Science Education, 1(1), 65 - 77.

Ertan, B. (1991). Türkiye’de çevre hakkının gelişimi. Ankara Üniversitesi, Yayınlanmamış Yüksek Lisans Tezi, Ankara.

Gül, F. (2013). İnsan-doğa ilişkisi bağlamında çevre sorunları ve felsefe. Pamukkale Üniversitesi Sosyal Bilimler Enstitüsü Dergisi, (14), 17-21.

Kahyaoğlu, M., Daban, Ş. \& Yangın S. (2008). İlköğretim öğretmen adaylarının çevreye yönelik tutumları. Dicle Üniversitesi Ziya Gökalp Ĕ̈itim Fakültesi Dergisi, (11), 42-52.

Kayalı, H. (2010). Sosyal bilgiler, Türkçe ve sınıf öğretmenliği öğretmen adaylarının çevre sorunlarına yönelik tutumları, Marmara Coğrafya Dergisi, (21), 258-268.

Meydan, A., \& Doğu, S. (2008). İlköğretim ikinci kademe öğrencilerinin çevre sorunları hakkındaki görüşlerinin bazı değişkenlere göre değerlendirilmesi, Selçuk Üniversitesi Ahmet Keleşoğlu Eğitim Fakültesi Dergisi, (26), 267-277.

Nisbet, E. K., Zelenski, J. M., \& Murphy, S. A. (2008). The nature relatedness scale: linking individuals' connection with nature to environmental concern and behavior. Environment and Behavior, 41(5), 715740 .

Onur, B. (1995). Gelişim psikolojisi. İmge Kitabevi, Ankara, 152.

Sam, N., Gürsakal, S., \& Sam, R. (2010). Üniversite öğrencilerinin çevresel risk algısı ve çevrese tutumlarının belirlenmesi. Akademik Bakış Uluslararası Hakemli Sosyal Bilimler E Dergisi, (20), 1-16.

Sam N., Sam R., \& Öngen B. K. (2010). Üniversite öğrencilerinin çevresel tutumlarının yeni çevresel paradigma ve benlik saygısı ölçeği incelenmesi. Akademik Bakış Uluslararası Hakemli Sosyal Bilimler E Dergisi, (21), $1-16$. 


\section{TÜRKÇE GENIŞLETILMIŞ ÖZET}

Doğa canlı ve cansız unsurlar bakımından çeşitlilik gösteren; etkileyen ve etkilenen, değiştiren ve değişebilen, yenilenebilme özelliklerine sahip; insan etkisi dişında oluşmuş; kendi mekanizmaları olan; sınırları kesinlik taşımayan açık bir sistemdir (Atasoy, 2006). Doğal çevre denildiğinde içinde doğa etkinliklerinin ve doğa güçlerinin oluştuğu, insan etkilerinin görülmediği veya önemli ölçüde değiştirilemeyen çevre akla gelmektedir. İnsanlar yaşamlarını devam ettirebilmek için doğal çevredeki kaynakları kullanarak, teknolojiyi geliştirerek, ekonomik etkinliklerde bulunarak doğal çevreden farklı olan yapay çevreyi oluştururlar. Yapay çevre içindeki yaşam koşullarını geliştirmeye çalışırken de doğa ile sürekli bir etkileşim içerisindedirler (Ertan, 1991). İnsan, yaşamını doğa içindeki koşulların etkisiyle yönlendiren ve mecburi olarak da doğayla ilişki içerisinde var olabilen bir varlıktır. Doğa, kendisi gibi canlı bir varlık olan insanla sürekli birlikte olmayı gerektirecek bir unsur olarak karşımıza çıkmaktadır. $\mathrm{Bu}$ zorunlu ilişki, insanın kendi ihtiyaçları ve öngörüleri etrafında şekillenmekte ve doğanın etkisini tek taraflı bir tutumla görmezden gelen insan kendi konumunu merkezileştirme yolunu seçmektedir (Gül, 2013). İnsan yeryüzünde yaşamaya başladığından bu yana kendisine ait yapay çevre oluşturmaya çalışmıştır, bu da insan ve doğa arasındaki ilişkinin sürekli doğa aleyhinde gelişmesine neden olmuştur. Doğal çevre ve yapay çevre arasında sürekli bir savaş söz konusudur. Doğal çevre günden güne daralırken, yapay çevre de sürekli büyüme çabasındadır (Ertan, 1991). Yapay çevrede meydana gelen büyümenin bireylere fark ettirilmesi ve çevreye duyarlı davranışlar geliştirilmesi için küçük yaşlardan itibaren konu ile ilgili eğitim verilmesi gerekmektedir (Çabuk, 2001). İnsan kimliğinin büyük bölümü, gelişim psikolojisi araştırmalarına göre çocukluk döneminin (0-12 yaş) ilk yıllarında oluşmaktadır. Evre kuramcıları (Sigmund Freud, Erik Erikson, Jean Piaget vb.) insan gelişimini evrelere ayırarak incelemişler ve sonuç olarak insan gelişiminin büyük oranda tamamlandığı çocukluk dönemindeki özelliklerinin diğer dönemleri etkilediği konusunda görüş birliğine varmışlardır (Onur, 1995). Gelişim psikolojisi alanında varılan bu sonucu, beyin bilimi alanında yapılan çalışma sonuçları da desteklemektedir (Çukur ve Özgüner, 2008). Çocukluk döneminden itibaren alınmaya başlanan doğa eğitimi konusuna verilen önem günümüzde giderek artmaktadır. Doğa eğitiminin ilköğretimin ilk kademesinde etkili ve nitelikli bir biçimde verilmesi için öğretmenlerin doğa eğitimi konusunda iyi yetişmiş olmaları gerekmektedir Birkaç yıl sonra ilköğretim öğrencilerini yetiştirecek olan öğretmen adaylarının nasıl bir doğa eğitimi verebileceklerini görmek için de öncelikli olarak doğayla ilişkilerinin belirlenmesinde yarar vardır. $\mathrm{Bu}$ araştırmada, öğretmen adaylarının doğayla ilişkileri çeşitli değişkenler açısından incelenerek ortaya konulmaya çalışılmıştır. Araştırmanın çalışma grubunu fen bilgisi ve sınıf öğretmenliği anabilim dalında öğrenim gören toplamda 363 öğretmen adayı oluşturmaktadır. Veri toplama aracı olarak "'Doğayla İlişki Ölçeği (DİÖ)" kullanılmıştır. Araştırma bulgularına göre; cinsiyet, öğrenim görülen bölüm ve sınıf düzeyi öğretmen adaylarının doğayla ilişkilerinde anlamlı farklılık $(\mathrm{p}<0.05)$ oluşturmuştur. Ancak öğretmen adaylarının doğayla ilişsilerinde çevre dersi alma durumu, doğa kuruluşuna üye olma durumu ve doğa etkinliğine katılma durumu değişkenlerine göre anlamlı farklılık olmadı tespit edilmiştir. Öğretmenlerin sadece öğretim alanında değil her alanda (eğitim, toplumsal, ahlaki, çevre, vb.) büyük sorumlulukları vardır. Çevreye duyarlı bireylerin olduğu toplumların oluşmasında aile ve öğretmenlerin atacağı temeller büyük önem taşımaktadır. Bu yüzden geleceğin öğretmenleri olacak öğretmen adaylarının doğayla olan ilişkilerinin güçlendirilmesi gerekmektedir. Fen Bilgisi ve Sınıf öğretmenliği programında öğrenim gören öğretmen adaylarının doğaya karşı farkındalıklarını artıracak etkinlik ve çalışmaların daha fazla yapılması gerekmektedir. Ayrıca öğretmen adaylarının doğayla olan ilişkileri farklı bağımsız değişkenlere göre incelenmesi gerektiği düşünülmektedir. 